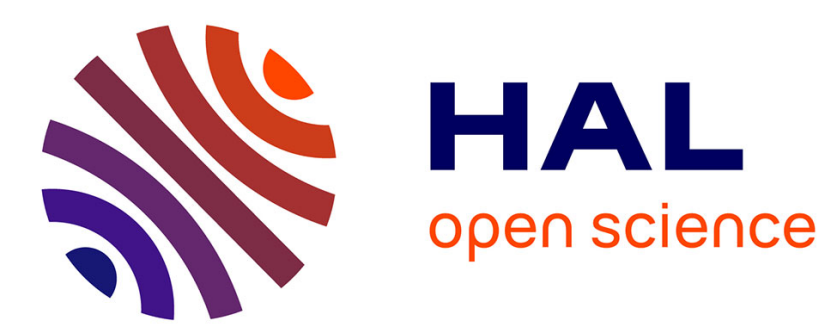

\title{
Dynamics of mangrove forests in the Mangoky River delta, Madagascar, under the influence of natural and human factors
}

\author{
Andriamparany Rakotomavo, François Fromard
}

\section{To cite this version:}

Andriamparany Rakotomavo, François Fromard. Dynamics of mangrove forests in the Mangoky River delta, Madagascar, under the influence of natural and human factors. Forest Ecology and Management, 2010, vol. 259, pp. 1161-1169. 10.1016/j.foreco.2010.01.002 . hal-00997388

\section{HAL Id: hal-00997388 \\ https://hal.science/hal-00997388}

Submitted on 28 May 2014

HAL is a multi-disciplinary open access archive for the deposit and dissemination of scientific research documents, whether they are published or not. The documents may come from teaching and research institutions in France or abroad, or from public or private research centers.
L'archive ouverte pluridisciplinaire HAL, est destinée au dépôt et à la diffusion de documents scientifiques de niveau recherche, publiés ou non, émanant des établissements d'enseignement et de recherche français ou étrangers, des laboratoires publics ou privés. 


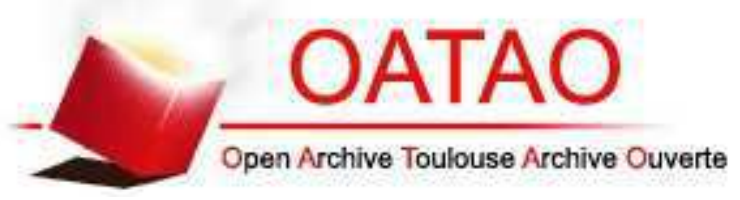

\section{Open Archive TOULOUSE Archive Ouverte (OATAO)}

OATAO is an open access repository that collects the work of Toulouse researchers and makes it freely available over the web where possible.

This is an author-deposited version published in : http://oatao.univ-toulouse.fr/ Eprints ID : 11706

To link to this article : doi:10.1016/j.foreco.2010.01.002

URL : http://dx.doi.org/10.1016/j.foreco.2010.01.002

To cite this version : Rakotomavo, Andriamparany and Fromard, François Dynamics of mangrove forests in the Mangoky River delta, Madagascar, under the influence of natural and human factors. (2010) Forest Ecology and Management, vol. 259 ( $\mathrm{n}^{\circ}$ 6). pp. 1161-1169. ISSN 0378-1127

Any correspondance concerning this service should be sent to the repository administrator: staff-oatao@ listes-diff.inp-toulouse.fr 


\title{
Dynamics of mangrove forests in the Mangoky River delta, Madagascar, under the influence of natural and human factors
}

\author{
Andriamparany Rakotomavo ${ }^{\text {a,*, François Fromard }}$ b,c \\ a Bureau d'études SAVAIVO, B.P. 8186, Ambatobe, Antananarivo, Madagascar \\ ${ }^{\mathrm{b}}$ Université de Toulouse, UPS, INP, EcoLab (Laboratoire d'écologie fonctionnelle), 29 rue Jeanne Marvig, F-31055 Toulouse Cedex, France \\ ${ }^{\mathrm{c}}$ CNRS, EcoLab, F-31055 Toulouse, France
}

Keywords:

Dynamics

Madagascar

Mangrove

Mapping

Remote sensing

\begin{abstract}
A B S T R A C T
Mangroves in Madagascar cover 327000 ha to 340300 ha. Several authors have studied these mangroves, but we do not yet have a complete knowledge of these ecosystems. The present study is an attempt to respond to this concern by analyzing dynamics and changes in the extent of the mangrove forest in the Mangoky delta (SW Madagascar) between 1951 and 2000. The comparison between base maps and Landsat TM images shows that the mangrove area remained relatively stable, even increasing slightly (+189 ha) between 1951 and 1979. From 1979 to 1994, its area decreased from 21426 ha to 11706 ha ( -9720 ha). It then increased again (+84 ha) between 1994 and 2000. The balance was a decrease of $41.74 \%$ between 1951 and 2000 . These figures may be compared with national ( $-15 \%$ in 56 years) and world ( $-35 \%$ for the last 20 years) statistics. Three main reasons are given to explain these changes: (1) the hydrological and sedimentological behavior of the Mangoky River; (2) the mechanism of plant succession, which depends on tides and on the characteristics of the substratum and (3) human activities and logging, which have increased since the 1980s in the Mangoky delta.
\end{abstract}

\section{Introduction}

Mangroves in Madagascar have been estimated to cover an area from about 327000 ha (Kiener, 1966; Rasolofo, 1993) to 340300 ha (from the map by Faramalala, 1996). They constitute $2 \%$ of the world's mangroves (Ioniarilala, 2000), and $9 \%$ of the African mangroves, just behind Nigeria (32\%) and Mozambique (12\%) (FAO, 2007). Of these, $98 \%$ lie on the west coast of Madagascar (Kiener, 1972). They belong to the Indo-Pacific region (Macnae, 1963) and comprise nine species characteristic of East Africa, according to SECA (1986). If most of the mangrove specialists agree with these general data, it is surprising to note that the evaluation of mangrove area changes and of mangrove uses in Madagascar was very different from an author to another, peculiarly for recent years.

Lebigre (1984) and Blasco (1991) pointed to these mangroves as being especially threatened, as they are very "sensitive and necessary" ecosystems. Spalding et al. (1997) established, in the 1st edition of the World Mangrove Atlas, that "human uses of the mangroves (in Madagascar) were limited in extent", related to the relatively low population density in most mangrove areas

\footnotetext{
* Corresponding author. Tel.: +261331169347.

E-mail addresses: andri.savaivo@blueline.mg (A. Rakotomavo), francois.fromard@cict.fr (F. Fromard).
}

combined with the availability of other timber and fuelwood sources. The authors added nevertheless that pressure on such areas "could increase considerably in the future". Otherwise, in a report published in 2007 by FAO (Table 6, p. 17), mangrove surfaces in Madagascar were estimated to be stable from 1980 to 1990, while it was established by PNUD (1998) for the same decade that they decreased of $40 \%$ (Table 24, p. 201). For the next periods and from FAO (2007) mangrove areas decreased of 15000 ha between 1990 and 2000 - corresponding to an annual loss of 1500 ha - and of 15000 ha from 2000 to 2005, i.e. 3000 ha/year loss on this period. In a more recent paper dealing with a comprehensive assessment of mangrove forest areas in Madagascar, Giri and Muhlhausen (2008) confirmed that mangrove deforestation rate varied both spatially and temporally in this country, and estimated that Malagasy mangrove areas slightly increased from 1975 to 1990 (5.6\%), then decreased from 1990 to 2005 , with a global loss of $7 \%$ of mangrove forests from 1975 to 2005.

Considering the total area of mangrove forests in the world, Valiela et al. (2001) estimated their decrease to 35\% during the last two decades. More recently, Giri et al. (2007) confirmed that areas of mangroves are decreasing all over the world at an alarming rate, possibly more rapidly than any other type of tropical forests. However, in their study area (Sunderbans, Bangladesh and Indian coasts), these authors observed a very active natural dynamics, linked to sedimentological processes, and an over-exploitation of 


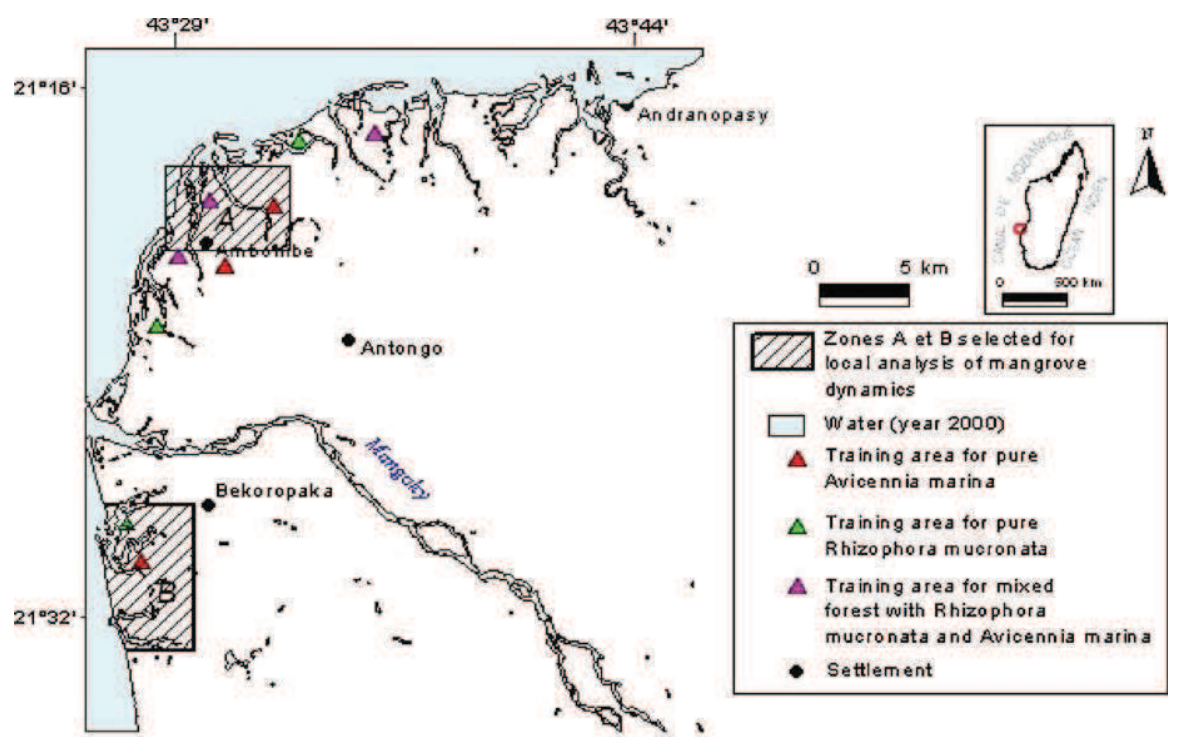

Fig. 1. Location of the study area.

resources of mangrove forest, but a relative stability of mangrove surface area.

The various physiognomic types of mangrove stands, from the coastal fringe to the bare and salted areas ("tannes"), through the real mangrove forests, participate to the coastline protection and make drainage processes more regular. Their ecological and biological roles are unique (wood provision, water storage, provision of nurseries and habitat for several species of invertebrate and vertebrate animals) (Rasolofo, 1993). Mumby et al. (2004) pointed out the particular importance of mangroves in the structure of fish communities. Therefore, "depletion starts being perceptible in Malagasy mangroves: decreasing fish catches, rapid deforestation, coastline erosion, extension of tannes, disorganization of the river network" (Rasolofoharinoro et al., 1998).

As a signatory of the Ramsar Convention, Madagascar, within the framework of its coastal zones sustainable development policy, adheres to the principle of "Integrated Coastal zone" (ICZM), commonly used in international agreements and treaties such as those elaborated on by UNEP ${ }^{1}$ and IPCC. ${ }^{2}$ In order to implement an ICZM, an "environmental diagnosis" is first necessary. Moreover, Dugan (1992) proposed that this diagnosis should be taken into account in a regional policy for the conservation of African humid zones.

Unfortunately, very little reliable and recent scientific data exist on mangroves in Madagascar (Diop, 1993; Lebigre, 1999), especially regarding regeneration or dynamics. However, some local studies should be mentioned, particularly in relation to the southwestern (Bigot, 1971; Derijard, 1963; Weiss, 1972), the northwestern (Ioniarilala, 2000; Pasqualini et al., 1999; Rasolofoharinoro et al., 1998), the eastern and the western parts of the island (various studies carried out within the framework of the CNRE-ORSTOM Mangrove Program in the 1990s).

According to Lebigre (1984), "Malagasy mangroves are very poorly understood and we do not have in hand the elements needed for a good diagnosis." This assertion is still true particularly in the case of the "very large mangroves of Mangoky" (Kiener, 1972), one of the marine swamps for which a prior investigation was necessary. With the exception of the study by Oliva and Salomon (1984), which used remote sensing, these mangroves are

\footnotetext{
${ }^{1}$ United Nation Environment Program.

2 Intergovernmental Panel on Climate Change.
}

still unexplored and there is much work still to be carried out in order to produce an ecological and socio-economic diagnosis.

The present study is an attempt to give a partial response to these scientific needs: (1) by determining the area and the present status of the mangrove forest in the Mangoky delta, (2) by analyzing the changes that have occurred between 1951 and 2000, and (3) by deducing the natural and human causes of this evolution.

\section{Materials and methods}

\subsection{The study area}

Located on the west coast of Madagascar, south of Morondava, the study area lies between $43^{\circ} 26^{\prime}$ and $43^{\circ} 46^{\prime}$ East, and $21^{\circ} 15^{\prime}$ and $21^{\circ} 35^{\prime}$ South. This area constitutes the Mangoky River delta (Fig. 1 ). The climate is tropical semi-arid, with a mean annual rainfall of about $400 \mathrm{~mm}$ distributed over 30-50 days/year between November and March, and decreasing from the north to the south. The tidal range on the west coast is about $3.5 \mathrm{~m}$.

The whole delta extends over 57280 ha, of which 11790 ha were mangrove forest in 2000. The delta is a part of the wide Mangoky watershed $\left(55750 \mathrm{~km}^{2}\right)$, the rivers of which originate in the Madagascar Central Highlands. The substratum is mainly made of sand and alluvium on a post-Miocene geological formation. Older alluvial layers are essentially sandy clay, covered with coarse rubified sand. Recent alluvium is silty and micaceous, making it excellent for growing crops.

The forest mangroves of the Mangoky delta are made up of six main tree species: Avicennia marina (Forsk.) Vierh., Xylocarpus granatum König, Ceriops tagal (Perr.) C.B. Rob., Rhizophora mucronata Lamk, Bruguiera gymnorrhiza (L.) Lamk., and Sonneratia alba J. Smith. Two other species (Lumnitzera racemosa Willd. and Heritiera littoralis Buch.-Ham.) are present in the area with a very localized distribution.

\subsection{Data and image processing}

The following data were used to analyze the evolution of land cover in the Mangoky delta:

- Landsat TM satellite imagery from 19 June 1994,

- Landsat ETM+ satellite imagery from 27 June 2000, 
- Base maps from the National Geographic and Hydrologic Institute of Madagascar (FTM), specifically BD 500 (1/500 000), and sheet BC 53 (1/100 000) published in 1952 (based on aerial photographs from 1951) and revised in 1980 (from aerial photographs from 1979). The two maps from 1952 and 1980 had the same projection as the BD 500, i.e. Gauss-Laborde Projection.

It is important to note that satellite images and aerial photographs were all taken between June and August, i.e. during the dry season. The two images from 1994 and 2000 were processed using IDRISI ${ }^{\circledR} 3.2$ software.

The 2000 image, geometrically corrected by FTM and georeferenced using the base map BD 500, was used to georeference the 1994 image. The RMS errors computed from more than 10 homologous points on images and maps were $30 \mathrm{~m}$ in $x$ and $51 \mathrm{~m}$ in $y$. We worked on $55750 \mathrm{~km}^{2}$ windows extracted from 1994 and 2000 Landsat images, corresponding to the whole Mangoky delta, and where all types of land use and mangrove facies were represented.

Color composites were made using band 1-5 of Landsat images (visible, near and mid-infrared) with the following combinations: bands 3-2-1 (natural-color composition), 4-3-2 and 4-5-1 (falsecolor composition). Band 6 (thermal infrared) peculiarly interesting for the discrimination of land cover classes in the dry tropical forests (Southworth, 2004) and generally not used for mangrove forest analyses (Giri et al., 2007) has not been taken into account in this study. Band 7, associated with bands 1-5, was used for Principal Component Analysis (PCA) and to produce, through a non-supervised classification, a pre-map with 11 unsupervised land use classes (Ramirez-Garcia et al., 1998).

After fieldwork (analysis of training areas and vegetation plots identified from the pre-map, see below) supervised classifications were performed (confusion matrix, accuracy probabilities) and 11 supervised-classes were established.

Thematic analysis was carried out with the aim of characterizing the evolution of the mangrove areas and the river network in 1951, 1979, 1994 and 2000, by comparing base maps and satellite data. This was carried out using the GIS Arc View ${ }^{\mathbb{R}}$ and it consisted of:

- Superimposing maps and images,

- Extracting from the study area two representative zones, A and B, to indicate changes in the land cover on a larger scale over the whole delta. The choice of zones A and B was controlled by their accessibility, their location within the delta (A to the north, B to the south) and the fact that they formed part of both the coastline and the land,

- Exporting from IDRISI to Arc View the classified images and computing the various units of land cover,

- Recording changes in the morphology of river courses and ponds, and deducing from these observations the causes and mechanisms of changes in the delta.

\subsection{Analysis of mangrove stand structure and measurement of ecological parameters}

Structural analyses have been conducted on the field with the following design:

- First, considering the 2 years time gap between the acquisition of satellite images (2000) and fieldwork (2002), and to be sure not to take into account new established stands in analyses, we selected only forest stands more than five years old as training areas. To estimate mangrove stand age, we have both considered mean stand height and mean diameter of individuals and knowledge of the local inhabitants about mangrove stand development.
- In each of the three main representative types of mangrove stands of the study area, i.e. pure A. marina stands, pure $R h$. mucronata stands and mixed Rhizophora-Avicennia (70-40\%), three plots have been chosen corresponding to different densities of mangrove tree populations, respectively low density (less than 3000 trees ha ${ }^{-1}$ ), medium density (3000-8000 trees ha ${ }^{-1}$ ) and high density (more than 8000 trees ha $^{-1}$ ). These nine $100 \mathrm{~m} \times 100 \mathrm{~m}$ plots, representing one density class in each forest type, were located with a GPS so they could be used as training areas and control zones in image processing.

- In each of these plots, four $10 \mathrm{~m} \times 10 \mathrm{~m}$ quadrats were selected at random, and all individual trees were recorded. Tree density, diameter at breast height (or $30 \mathrm{~cm}$ above the uppermost intersection of the prop roots for Rhizophora when intersections where up to $1.30 \mathrm{~m}$ ) and height were measured, and then basal areas were computed (Fromard et al., 1998). Thirty-six $10 \mathrm{~m} \times 10 \mathrm{~m}$ quadrats in the whole were then used for structural analysis.

Due to local and material constraints, only few ecological measurements were made directly on the field, i.e. conductivity or total suspended solid concentration (SSC) in water bodies, through a multiparameter water quality portable meter, from the water surface to $1.20 \mathrm{~m}$ depth. Sediment cores samples were taken for analyses in laboratory (CNRE Madagascar, National Center for Environmental Research) and complete results will appear in a next document (Rakotomavo, 2010).

\section{Results}

\subsection{Image analysis}

Our main aim is to analyze land cover change within the Mangoky delta-and more peculiarly changes in mangrove communities, at a regional scale. So, it is necessary to evaluate the accuracy level of imagery analysis processes, which allow to extrapolate from local level (field plots) to regional scale.

Principal component analysis applied to bands $1-5$ and 7 of Landsat ETM+ (2000) showed that the three first components explained $99.34 \%$ of the total variance of the data (Table 1). From this analysis, we defined, through unsupervised classification, 11 land use classes, including three mangrove classes where training areas and field sample plots have been located, i.e. pure A. marina forest, pure Rh. mucronata forest, mixed forest with $A$. marina and Rh. mucronata.

By the mean of classification error matrix (Table 2) and calculation of omission and inclusion probabilities (Table 3 ), assessment of supervised classification was established. Classification error matrix showed that $83 \%$ of sampled pixels were well classified, with a total accuracy of $84.4 \%$. Regarding mangrove pixel classification, we obtained respectively $83.8 \%, 85 \%$ and $86.7 \%$ of well-classified pixels for pure A. marina stands, $R h$. mucronata stands, and mixed stands. Finally we noted that accuracy rates were greater than $80 \%$ for producer and user.

\subsection{Mangrove status in 2000}

Considering field observations, map analyses and above image processes, we established structural and surface characteristics of mangrove stands in study area.

In 2000, the Mangoky River delta supported 11790 ha of mangrove, divided into three main types as followed (Fig. 2):

- Mixed forest with A. marina and Rh. mucronata (around 4550 ha), - Pure A. marina forest (around 5116 ha),

- Pure Rh. mucronata forest (around 2124 ha). 
Table 1

Principal components (PC) matrix (eigenvectors) and percentage of variance for the six used bands of Landsat ETM+ (2000).

\begin{tabular}{llrrrrr}
\hline Components & Band 1 & Band 2 & Band 3 & Band 4 & Band 5 & Band 7 variance \\
\hline 1st PC & 0.117 & -0.320 & 0.225 & -0.050 & 0.415 \\
2nd PC & 0.195 & -0.381 & 0.386 & -0.049 & 0.812 & -0.572 \\
3rd PC & 0.369 & -0.481 & 0.323 & -0.250 & -0.683 & -0.581 \\
4th PC & 0.381 & 0.670 & 0.617 & 0.144 & -0.026 & 0.002 \\
5th PC & 0.638 & 0.198 & -0.474 & -0.544 & 0.180 & -0.060 \\
6th PC & 0.509 & -0.183 & -0.301 & 0.785 & -0.026 \\
\hline
\end{tabular}

Table 2

Classification error matrix for the supervised classification.

\begin{tabular}{|c|c|c|c|c|c|c|c|c|c|c|c|c|}
\hline Classes & $\mathrm{Rz}$ & RA & $\mathrm{Av}$ & Та & $\mathrm{Mr}$ & Wt & Sd & Df & Gs & Ts & $\mathrm{Cp}$ & $\sum$ Real + inclusion \\
\hline $\mathrm{Rz}$ & 190861 & 3 & 56 & 310 & 30099 & 3667 & 700 & 3 & 3469 & 15 & 246 & 229429 \\
\hline RA & 1 & 20491 & 2806 & 33 & 477 & 56 & 0 & 0 & 1 & 0 & 3 & 23868 \\
\hline Av & 67 & 2415 & 41628 & 2577 & 1362 & 11 & 0 & 0 & 2 & 5 & 180 & 48247 \\
\hline Та & 166 & 85 & 2971 & 45647 & 3471 & 128 & 2127 & 3 & 55 & 41 & 1352 & 56046 \\
\hline $\mathrm{Mr}$ & 24064 & 513 & 2064 & 3560 & 383780 & 11896 & 5909 & 2035 & 35662 & 1131 & 2625 & 473239 \\
\hline Wt & 4603 & 106 & 9 & 671 & 18903 & 78487 & 460 & 8 & 757 & 1 & 52 & 104057 \\
\hline Sd & 545 & 0 & 7 & 2651 & 8409 & 128 & 40967 & 204 & 2507 & 287 & 144 & 55849 \\
\hline Df & 0 & 0 & 0 & 1 & 1315 & 35 & 22 & 77655 & 5936 & 1750 & 44 & 86758 \\
\hline Gs & 3612 & 1 & 2 & 41 & 53768 & 327 & 2194 & 6172 & 177057 & 803 & 82 & 244059 \\
\hline Ts & 167 & 5 & 38 & 152 & 2180 & 25 & 93 & 3566 & 531 & 23423 & 3200 & 33380 \\
\hline Cp & 487 & 3 & 81 & 816 & 1316 & 28 & 22 & 34 & 33 & 837 & 424251 & 427908 \\
\hline$\sum$ Real + inclusion & 224573 & 23622 & 49662 & 56459 & 505080 & 94788 & 52494 & 89680 & 226010 & 28293 & 432179 & 1782840 \\
\hline
\end{tabular}

$\mathrm{Rz}=$ Rhizophora mucronata; $\mathrm{RA}=$ Rhizophora mucronata and Avicennia marina; Av=Avicennia marina; Ta = bare and/or herbaceous tanne (on tidal area)-grass savanna (on mainland); $\mathrm{Mr}$ =foreshore and/or marsh; $\mathrm{Wt}=$ water; $\mathrm{Sd}=$ sand and/or bare soil; $\mathrm{Df}=$ dry forest; Gs = grass savanna; $\mathrm{Ts}=$ tree savanna; $\mathrm{Cp}=\mathrm{crops}$

Table 3

Evaluation of the supervised classification.

\begin{tabular}{lllll}
\hline Classes & $\begin{array}{l}\text { Producer's } \\
\text { accuracy (\%) }\end{array}$ & $\begin{array}{l}\text { Omission } \\
\text { probability (\%) }\end{array}$ & $\begin{array}{l}\text { User's } \\
\text { accuracy (\%) }\end{array}$ & $\begin{array}{l}\text { Inclusion } \\
\text { probability (\%) }\end{array}$ \\
\hline $\mathrm{Rz}$ & 82.77 & 17.23 & 80.77 & 19.23 \\
$\mathrm{RA}$ & 86.57 & 13.43 & 85.66 & 14.34 \\
$\mathrm{Av}$ & 83.37 & 16.63 & 85.89 & 14.11 \\
$\mathrm{Ta}$ & 80.23 & 19.77 & 80.84 & 19.16 \\
$\mathrm{Mr}$ & 67.31 & 32.69 & 73.62 & 26.38 \\
$\mathrm{Wt}$ & 81.74 & 18.26 & 74.05 & 25.95 \\
$\mathrm{Sd}$ & 77.33 & 22.67 & 72.54 & 27.46 \\
$\mathrm{Df}$ & 85.91 & 14.09 & 88.95 & 11.05 \\
$\mathrm{Gs}$ & 74.9 & 25.1 & 68.56 & 31.44 \\
$\mathrm{Ts}$ & 82.46 & 17.54 & 69.69 & 30.31 \\
$\mathrm{Cp}$ & 97.59 & 2.41 & 98.87 & 1.13 \\
Total accuracy=84.4\% & & & \\
\hline
\end{tabular}

$\mathrm{Rz}=$ Rhizophora mucronata; $\mathrm{RA}=$ Rhizophora mucronata and Avicennia marina; $\mathrm{Av}=$ Avicennia marina; $\mathrm{Ta}=$ bare and/or herbaceous tanne (on tidal area)-grass savanna (on mainland); $\mathrm{Mr}=$ foreshore and/or marsh; $\mathrm{Wt}=$ water; $\mathrm{Sd}=$ sand and/or bare soil; $\mathrm{Df}=\mathrm{dry}$ forest; $\mathrm{Gs}=$ grass savanna; $\mathrm{Ts}=$ tree savanna; $\mathrm{Cp}=$ crops

Forest density varied according to the forest type (Table 4). Avicennia forest had 5005 trees ha ${ }^{-1}$ (of which $37 \%$ regrowth with a height of less than $30 \mathrm{~cm}$ ). The mixed forest containing Avicennia and Rhizophora plants had 7188 trees ha $^{-1}$ (of which $33 \%$ regrowth with a height of less than $30 \mathrm{~cm}$, most of which being A. marina, Ceriops tagal and Rh. mucronata). The Rhizophora forest contained 8500 trees ha $^{-1}$.

Table 4

Area, density and regrowth percentage (seedlings less than $30 \mathrm{~cm}$ high) for the 3 mangrove forest types, in Mangoky delta.

\begin{tabular}{llll}
\hline Mangrove stands & $\begin{array}{l}\text { Surface area } \\
\text { in } 2000 \text { (ha) }\end{array}$ & $\begin{array}{l}\text { Density } \\
\text { (trees/ha) }\end{array}$ & $\begin{array}{l}\text { Regrowth } \\
(\%)\end{array}$ \\
\hline $\begin{array}{l}\text { Avicennia marina and } \\
\text { Rhizophora mucronata }\end{array}$ & 4550 & 7188 & 33 \\
$\begin{array}{l}\text { Pure Avicennia marina } \\
\text { Pure Rhizophora mucronata }\end{array}$ & 5116 & 5005 & 37 \\
\hline
\end{tabular}

The mean height of mature living trees was $6.22 \mathrm{~m}$ in the Avicennia forest. Their mean diameter and basal area were $12 \mathrm{~cm}$ and $18.98 \mathrm{~m}^{2} \mathrm{ha}^{-1}$, respectively. Their height was $5.19 \mathrm{~m}$ in the Rhizophora forest, with a diameter and basal area of $5 \mathrm{~cm}$ and $17.34 \mathrm{~m}^{2}$ ha $^{-1}$, respectively. In the mixed forest, trees were $6.10 \mathrm{~m}$ high on average, having a diameter of $7 \mathrm{~cm}$ and a basal area of $14.27 \mathrm{~m}^{2} \mathrm{ha}^{-1}$.

\subsection{Evolution of the area of mangrove distribution from 1951 to 2000}

By comparing the base maps and satellite images, changes in the area of mangrove distribution have been assessed (Table 5, Fig. 3).

- There was a slight increase of 6\%, i.e. 1189 ha, mangrove area going up from 20237 ha in 1951 to 21426 ha in 1979, corresponding to a mean increase of 42 ha year $^{-1}$ over 28 years. - From 1979 to 1994, nearly 9720 ha of mangrove forest disappeared. In other words, the forest area dropped from 21426 ha to 11706 ha within 15 years, which is a mean loss of 648 ha year $^{-1}$ over this period. Through a visual comparison of the 1979 and 1994 maps, it can be seen that most of the loss occurred in the inland part of the delta. The decreasing of mangrove areas was followed by the appearance of "tannes", specifically in the northern part of the delta (Fig. 2).

- Between 1994 and 2000, the dynamics was different, with a very slight increase of mangrove areas, from 11706 ha to 11790 ha.

Overall, there was a loss of $42 \%$ recorded in the mangroves of the Mangoky River delta, between 1951 and 2000.

\subsection{Mangoky River dynamics}

The lower course of the Mangoky River was clearly shown to have moved to the south, deserting the previous location of its mouth near Ambohibe (Fig. 1). The previous course appears on the 1951 and 1979 base maps, and consequently on more recent thematic documents based on these maps (Faramalala, 1996; Humbert and Cours-Darne, 1965). Salomon (1987) had already 


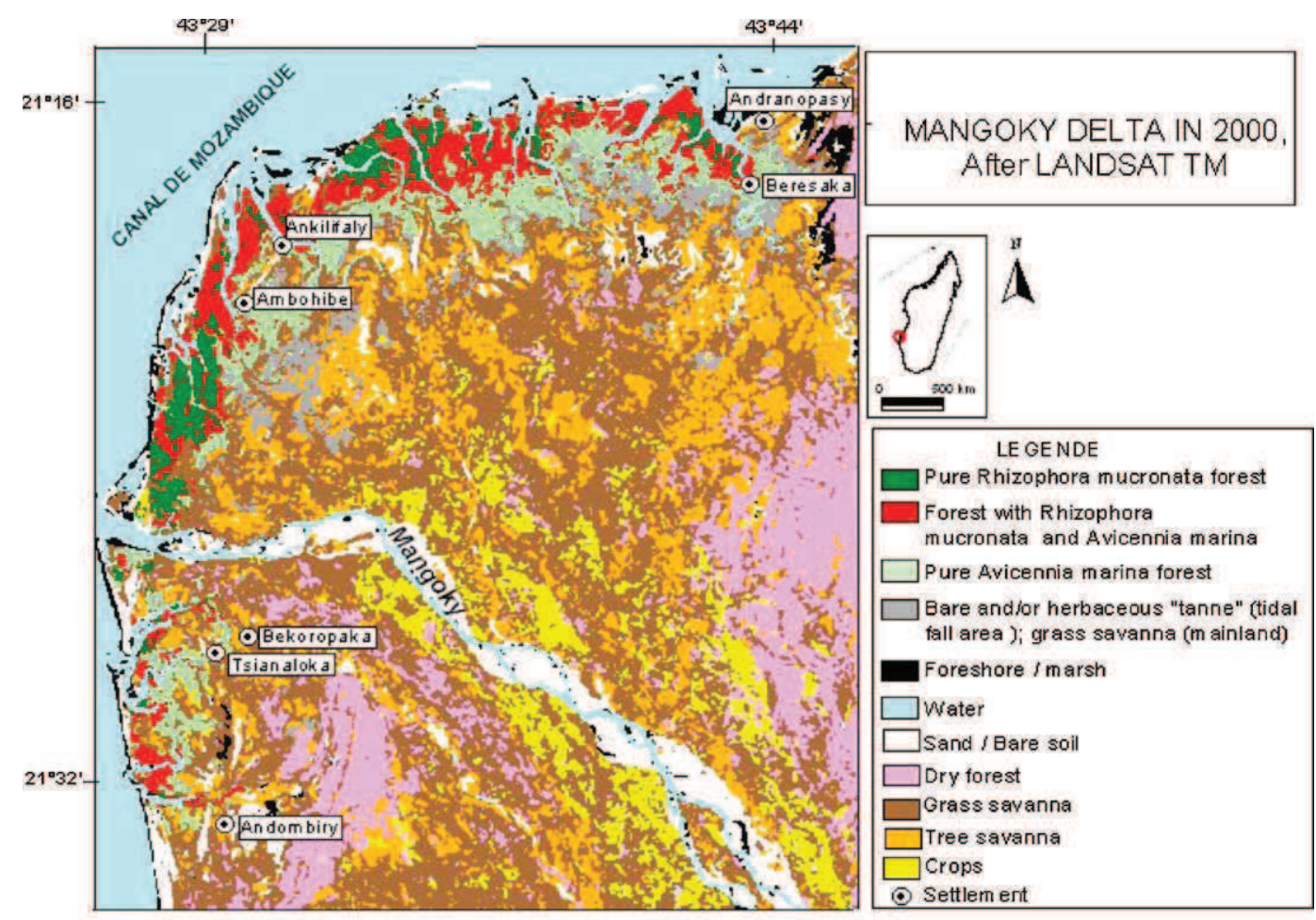

Fig. 2. Mangoky delta in 2000, from Landsat TM.

Table 5

Landcover changes in Mangoky delta between 1951 and 2000 (areas in hectares).

\begin{tabular}{lllll}
\hline Landcover types & 1951 & 1979 & 1994 & 2000 \\
\hline Mangrove & 20237 & 21426 & 11706 & 11790 \\
Continental dry forest & 23374 & 15891 & 59920 & 13144 \\
Tree savanna & 43717 & 49950 & & 42166 \\
Bare soil, sand, tree & 18865 & 18926 & 34567 & 39093 \\
$\quad$ savanna, tannes, & & & & \\
$\quad$ settlements, crops & & & & \\
\hline
\end{tabular}

noticed the tendency of the Mangoky River to shift southward. The Landsat TM data undoubtedly show the main course of the Mangoky River flowing into the sea to the north of Ankazomanga (Figs. 2 and 3).

Comparing the river courses in 1951, 1979 and 2000 shows the main course of the Mangoky shifting progressively southward between 1951 and 2000. The number of branches of the river increased noticeably during the period 1951-1979 and then reduced between 1979 and 2000 when the mouth began moving to the southern part of the delta.

\section{Discussion}

The mangrove dynamics in the Mangoky River delta can be explained by various interlinked factors: (i) shifting of the lower course of the Mangoky River, (ii) pioneering and regression mechanisms in tidal zones, and, together with these natural causes, and (iii) human activities, which also play an important role in modeling the landscape in the delta.

4.1. Hydrological and sedimentological dynamics leading to alluvial deposits on back mangrove forests

According to Andriamasinoro (1993), "the river appears to be the basic element in building the delta landscape. The abundance or lack of clear water conditions hydrogeomorphological units and mangrove species distribution". The hydrodynamic behavior of the Mangoky River is directly related to the mechanism of alluvial deposits, as this enables mud accumulation, the filling up of channels, the shifting of watercourses and the formation of tidal channels in the delta.

So, due to different slopes upstream and downstream (0.7$3 \mathrm{~m} \mathrm{~km}^{-1}$ ) as well as the mean water speed in some parts $\left(3 \mathrm{~m} \mathrm{~s}^{-1}\right)$, floods, sediment deposits and hydromorphological processes can be spectacular (Andriamasinoro, 1993). Water flowing downwards spreads slowly on the gentle slopes of the delta and then meanders and branches out, rarely flowing in a straight line, while depositing tons of alluvium. In September 2002 (i.e. end of the dry season) we measured $48-209 \mathrm{mg} \mathrm{l}^{-1}$ of sediments in some of the branches of the Mangoky River. These values increased during the rainy (or flood) season up to $4 \times 10^{3} \mathrm{mg} \mathrm{l}^{-1}$, compared with $120 \mathrm{mg} \mathrm{l}^{-1}$ during times of medium flow (Chaperon et al., 1993). According to the same author, 5.5-19.2 million tons of sediments were recorded annually in the Mangoky River between 1951 and 1955. This sediment load corresponds to a mean erosion of $0.15 \mathrm{~mm}$ in the whole Mangoky watershed and granulometric analyses showed that they were made up of $20 \%$ clay, $20 \%$ silt, about $60 \%$ fine sand and at least $2 \%$ coarse sand.

These hydrological and sedimentological phenomena contributed to the mangrove dynamics, through two opposite processes:

- They facilitated the spread of mangrove seeds and seedlings, allowing mangrove regrowth on the sides of the river (SW and NW Ambohibe, Beresaka, Andranopasy and Ankilifaly (Figs. 2 and 4).

- They contributed to the decay and to the death of mangrove stands in some inland zones by the obstruction of channels. Massive deposition of sediments led to branches or main courses of rivers shifting. Between 1979 and 2000, the number of main river branches fell from three to one, the two northern Mangoky tributaries disappearing when they were filled with alluvium (Figs. 2 and 5). 


\section{MANGROVE FOREST CHANGES IN MANGOKY DELTA BETWEEN 1951 AND 2000}
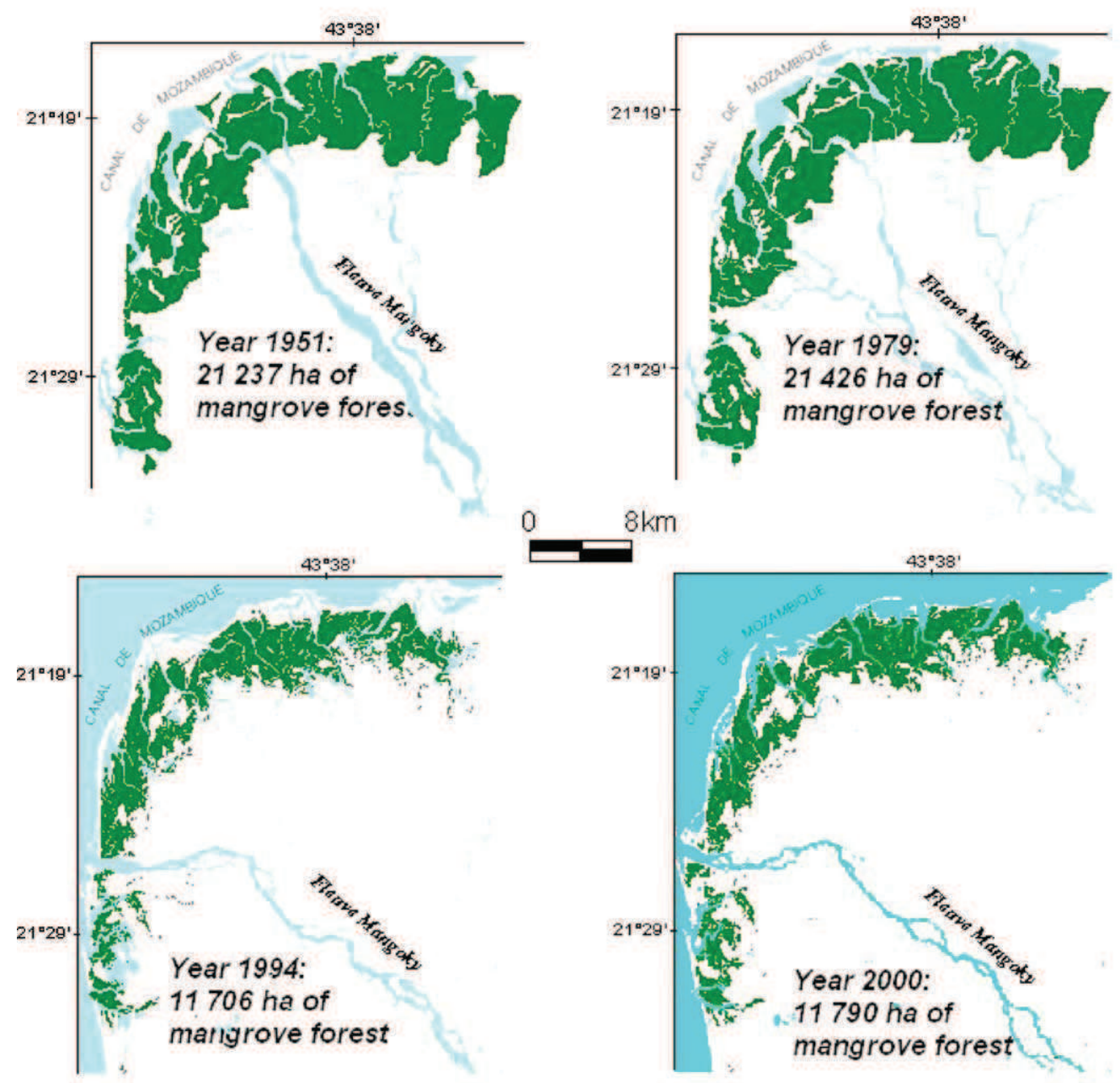

Fig. 3. Mangrove forest changes in Mangoky delta between 1951 and 2000.

4.2. General regression in back mangrove forests and development of tanne areas

Figs. 2 and 5 illustrate the regression in back mangrove forests between 1951 and 2000. On the 2000 map, only some patches of $A$. marina and $R h$. mucronata are recorded, as they can survive in the environmental conditions of Zone B (Fig. 5). Between 1951 and
2000 , about 768 ha of mangrove, i.e. $38 \%$ of the original area disappeared in this zone. In $2000,60 \%$ of the remaining forest consisted of Avicennia, with $35 \%$ being a mixed Avicennia/ Rhizophora forest. The previous mangrove forest was probably replaced by tannes. These changes in mangrove stand structure, i.e. decreasing but persistence of pure Avicennia stands, rarefaction or disappearance of other species, could have been caused by salinity

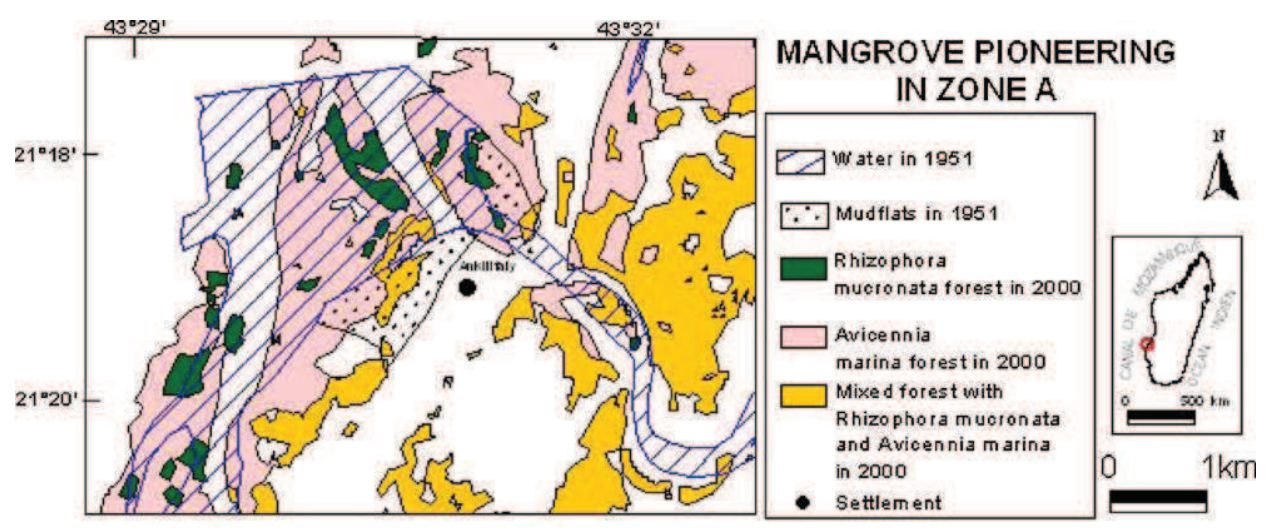

Fig. 4. Mangrove pioneering in Zone A. 

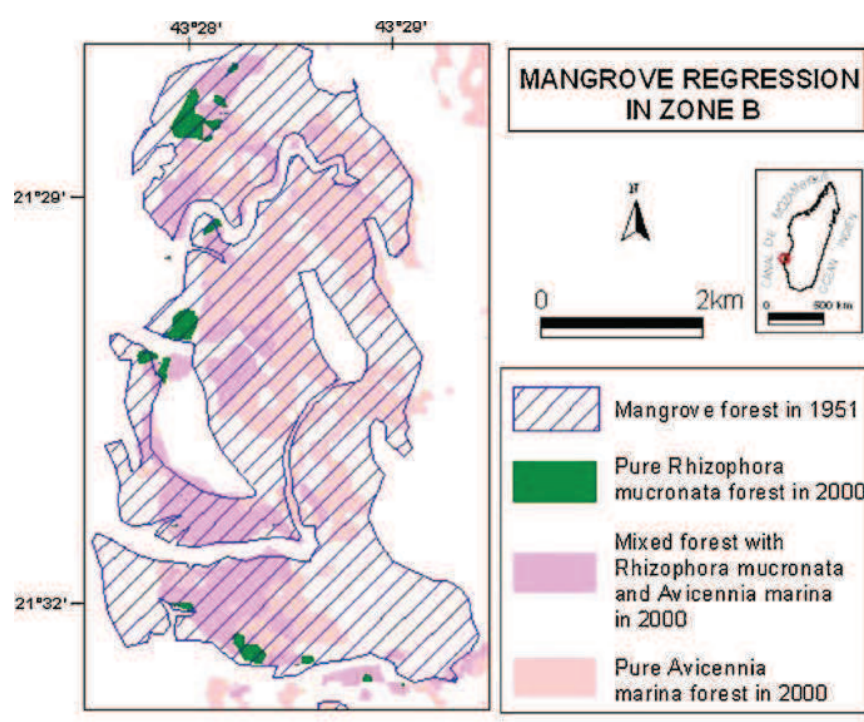
IN ZONE B

Fig. 5. Mangrove regression in Zone B.

increase and tannification processes, added to anthropogenic activities.

In order to explain these phenomena, Ranaivoson (1998) stated "that while river deposits accumulate seaward, mangrove forest extends downstream, whereas the soil rises towards the inland regions. This soil is only flooded during spring tides and then gives way to a tanne, i.e. prolonged dryness and excess salt due to evaporation lead to decaying of the mangroves". In such conditions, mangrove establishment becomes difficult, even unlikely. Only in some barren locations that become less saline due to sandy clay deposits, can halophytic plants such as Sporobolus spp. and Arthrocnemum spp. progressively grow.

Conductivity measurements made directly in different water bodies showed values from 46.6 to $60.9 \mathrm{~ms} \mathrm{~cm}^{-1}$ for Mangoky tributaries - i.e. around 30-39.7\% in terms of salinity - and from 59.5 to $78.4 \mathrm{~ms} \mathrm{~cm}^{-1}$ for mangrove creeks, i.e. $38.7-51.2 \%$. Higher values correspond to mangrove zones where $A$. marina, salt-tolerant species, is largely dominant and where $R h$. mucronata, saltintolerant one, is clearly decaying. Rasolofoharinoro et al. (1998) have previously established for mangrove stands in Madagascar that Rhizophora trees are limited in their distribution by mean water salinities exceeding 30\%, and that Avicennia trees could become stunted when water salinity approched $60 \%$. In Australia, Ball (1998) established that mangrove species richness analyzed along a river floodplain was minimal both in high salinity and drying environments and was the greatest in moderatily saline sites.

Elster's study in mangroves of Colombia (2000) confirmed that hypersalinization, increasing sediment deposits and lower water levels were the main causes of mangrove death. Hoffman et al. (1985) and Komiyama et al. (1996) reported the role of floods in Florida, and Cintron et al. (1978) and Jimenez (1990) stated the importance of salinity and the flowing of rivers in Puerto Rico and on the Pacific coast of Central America. According to these studies, it was observed that river floods, one of the necessary conditions for allowing mangroves to thrive, cannot penetrate anymore into some parts of the Mangoky delta. In places receiving such a deficient supply of water during tidal periods, mangrove stands were decaying, in relation with salinization and drying processes.

\subsection{Plant succession mechanism allowing mangrove expansion seaward}

Oliva and Salomon (1984), using Landsat MSS remote sensing data (from 1973) on the Mangoky delta confirmed anecdotal evidence of mangrove expansion seaward and young mangrove trees appearing in the delta. The spontaneous expansion of mangrove forest is not exceptional in delta and estuary environments where a large amount of sediment is regularly deposited. Ioniarilala (2000) recorded in NW Madagascar an annual net increase in mangrove forest of 14 ha between 1957 and 1996. This result is different from that obtained in our study area (about 42 ha year $^{-1}$ for the whole delta between 1951 and 1979). However, both cases illustrate the natural vegetation dynamics in an area influenced by river courses.

Generally, A. marina benefits more than other species from the growth of mudflats and is considered as a pioneer species in these environments. This was also observed by Weiss (1972) in S and SW Madagascar. We noticed in Zone A (Fig. 4) the spontaneous expansion of a mangrove forest in a region where human pressure was very low: the mangrove area increased from 1315 ha to 1394 ha between 1951 and 2000, i.e. a mean increase of 1.7 ha year ${ }^{-1}$ over 49 years. As shown in Fig. 4, nearly five-sixths of the area occupied by water in 1951 had been invaded by mangrove forest in 2000. It can also be seen (Fig. 4) that $90 \%$ and $50 \%$ of the two mudflats in 1951 (to the west and to the north of Ankilifaly, respectively) had been invaded by $A$. marina and/or $R h$. mucronata by 2000.

Other studies carried out in different parts of Madagascar (Andriamasinoro, 1993; Ioniarilala, 2000), in Vietnam (Hong and San, 1993), as well as in other African and Asian countries, emphasize the same succession mechanism after the deposition of sediment. That is, Avicennia spp. first becomes established in places with large tidal ranges that are supplied with large amounts of alluvium that have high salinity. In some places that are more exposed to tides, Sonneratia spp. is the pioneer species. After the substratum has become elevated due to sediment deposition, other species such as Rhizophora spp. appear on the landward fringe, where conditions are calmer and where ecological ranges are lower, specifically relating to salinity and flooding.

Fieldwork confirms that there is no transition between A. marina and $R h$. mucronata stands. The boundary between the two types is generally sharp, except for a thin fringe of Avicennia containing a few Rhizophora trees $\left(0.1-1\right.$ tree $\left.\mathrm{m}^{-2}\right)$ mixed through it. The whole forest is generally closed and dead trees give way to regeneration, as we noticed to the north of Ankilifaly and in Ambohibe. Recruitment is greater than the number of dead trees in the coastal fringe. The balance in these places showed no loss between 1951 and 2000, as the pioneering mechanism is rather efficient.

\subsection{Heavy pressure by humans since the early eighties}

Mangrove forest regression between 1979 and 2000 is also the result of heavy pressure from human habitation. With a loss in area of about $45 \%$ over 15 years (1979-1994), the Mangoky delta mangrove had a deforestation rate higher than the rate for all of Madagascar during the period 1980-1990 and for the whole world for the last two decades (Valiela et al., 2001).

In the delta, mangrove forest supplies wood to fishermen living on the coast as well as to the farmers in inland areas. Following the restoration of hydro-agricultural works, the 1980s were marked by masses of migrants arriving and clearing the delta again. Slashand-burn practices (hatsaky), grazing cows and small ruminants, and an increasing need for firewood and timber had a negative impact on the extent of the mangrove forest. In fact, due to a strong decrease in the supply of inland species for human use (i.e., Dalbergia spp., Cedrelopsis grevei Baill., Commiphora spp., Tamarindus spp.), because they are generally protected either by local tradition or by forest regulation, mangrove forests become a useful alternative resource for inland people (Rakotomavo and Fromard, 2009). 
So, since the 1980s, mangrove species have become much more valued. People enter mangrove stands looking for the species that are most convenient for cooking and building. Rhizophora and Bruguiera are the most sought-after genera.

Therefore, according to Lebigre (1984), "each species has its own qualities: B. gymnorrhiza has a straight trunk that gives standard poles $5 \mathrm{~m}$ high. It is more sought after than $R$. mucronata, which has the same characteristics. H. littoralis is used for timber beams. On the other hand, A. marina provides better firewood." Therefore, searching for new stands containing Rhizophora or other interesting species has become unavoidable since the 1990s. For example, a family needs one cart of firewood monthly, i.e., nearly 2.4-2.6 tons year ${ }^{-1}$. For such a quantity, it is necessary to clear-cut yearly at least half a hectare of Rhizophora forest more than $6 \mathrm{~m}$ high, with a mean diameter of more than $6 \mathrm{~cm}$ and a stand density up than 500 trees ha ${ }^{-1}$.

\section{Conclusion}

Through Landsat TM image processing supported by fieldwork, mangrove maps of the Mangoky River delta were carried out Three vegetation types were recognized in the delta: a mixed forest containing A. marina and $R h$. mucronata (4550 ha), a forest of pure A. marina (5116 ha) and a forest of pure Rh. mucronata (2124 ha).

In addition, a comparison between several base maps and satellite images from various dates using GIS showed clearly, for the first time, a spectacular shifting of the Mangoky River mouth between 1951 and 2000. This phenomenon is not rare in deltas, but no cartographic document had recorded this change up to now. The large mangrove forest on the delta is consequently affected by this shifting of the river. Because the northern delta was not sufficiently irrigated by the river, back mangrove trees decayed and gave place to large tannes. While the delta contains pioneer mangroves as well as decaying mangroves, calculating mangrove area changes, however, shows a negative balance between 1951 and 2000 .

This significant mangrove regression over the last 30 years is a feature that the Mangoky delta has in common with other coastal areas in Madagascar (south, NW and N-NW). Nevertheless the mangrove loss in the Mangoky delta, 41.7\% between 1951 and 2000 , seems to be higher than in other parts of Madagascar, as established by Valiela et al. (2001), which reported a loss of $15 \%$ for the whole country from 1921 to 1997, and a loss of more 35\% for the world's mangrove area during the last two decades.

In the case of the Mangoky delta, periods of regression (19791994 and 1994-2000) and periods of expansion (1951-1979) were found, with an important loss of 10000 ha between 1979 and 1994. This last figure suggests that human influence is an important cause of the destruction. The arrival of masses of migrants in the 1980s seems to have caused a sudden regression of the mangrove forest, but this phenomenon is likely to stabilize from the 1990s onwards.

Finally, the mangrove forest dynamics in the Mangoky delta appears as correlated to the delta functioning. The main threat comes from human activities, which have to change in order to avoid environmental disturbance.

\section{Acknowledgements}

The first author is a doctoral researcher, funded by the SCAC (Service de Coopération et d'Action Culturelle) of the France Embassy in Madagascar, through the CAMPUS/CORUS Project no. 98518120.

Authors are also grateful to Marie-France Bellan, who participated in remote sensing processing and mapping. We also thank two anonymous reviewers for their very useful criticism and suggestions for improvement.

\section{References}

Andriamasinoro, S.M., 1993. Mobilité: réponses des sociétés paysannes face à l'instabilité des conditions naturelles d'un milieu deltaïque. Exemples de quelques villages du delta de la Tsiribihina, centre ouest de Madagascar. Mémoire de l'Ecole Normale Supérieure, Université d'Antananarivo, 92 pp.

Ball, M.C., 1998. Mangrove species richness in relation to salinity and waterlogging: a case study along the Adelaide River Floodplain, Northern Australia. Global Ecology and Biogeography Letters 7 (1), 73-82.

Bigot, L., 1971. Contribution à l'étude écologique des peuplements halophiles de la région de Tuléar. II. La plage et le cordon dunaire. Annales de l'Université de Madagascar 7, 159-163.

Blasco, F., 1991. Aménagement d'écosystèmes forestiers fragiles. Revue Forestière Française 4, 383-390.

Chaperon, P., Danloux, J., Ferry, L., 1993. Fleuves et rivières de Madagascar. In: Monographie Hydrologique, vol. 10, ORSTOM, Paris, 874 pp.

Cintron, G., Lugo, A.E., Pool, D.J., Morris, G., 1978. Mangroves of arid environments in Puerto Rico and adjacent islands. Biotropica 10,110-121.

Derijard, R., 1963. Contribution à l'étude du peuplement des sédiments sablovaseux et vaseux intertidaux compactés ou fixés par la végétation de la région de Tuléar. Etudes malgaches, XVII, Université de Madagascar, 94 pp.

Diop, E.S. (Ed.), 1993. Conservation et utilisation rationnelle des forêts de mangrove de l'Amérique Latine et de l'Afrique. Mangrove Ecosystems Technical Reports, ISME/ITTO/COMAR 3, 267 pp.

Dugan, P.J., 1992. Wetlands management: a critical issue for conservation in Africa. In: Wetlands Conservation Conference for Southern Africa (IUCN Wetlands Programme). pp. 1-8.

Elster, C., 2000. Reasons for reforestation success and failure with tree mangrove species in Colombia. Forest Ecology and Management 131, 201-214.

FAO (Ed.), 2007. The world's mangrove 1980-2005. FAO Forestry Paper 153, Rome Italy, $78 \mathrm{pp}$.

Faramalala, M.H., 1996. Carte des Formations Végétales de Madagascar. 1:1 000000,3 sheets. I.C.I.V., Toulouse, France.

Fromard, F., Puig, H., Mougin, E., Marty, G., Betoulle, J.L., Cadamuro, L., 1998 Structure, above-ground biomass and dynamics of mangrove ecosystems: new data from French Guiana. Oecologia 115, 39-53.

Giri, C. Pengra, B., Zhu, Z, Singh, A., Tieszen, L.L. 2007. Monitoring mangrove forest dynamics of the Sundarbans in Bangladesh and India using multi-temporal satellite data from 1973 to 2000. Estuarine, Coastal and Shelf Science 73, 91 100.

Giri, C., Muhlhausen, J., 2008. Mangrove forest distributions and dynamics in Madagascar (1975-2005). Sensors 8, 2104-2117.

Hoffman, W.E., Durako, M.J., Lewis III, R.R., 1985. Habitat restoration in Tampa Bay. In: Treat, S.A.F., Simon, J.L., Lewis, III, R.R., Whiteman, R.L. (Eds.), Proc. Tampa Bay Area Scientific Inf. Symp. Florida Sea Grant College, Bellwether Press, pp. 636-657.

Hong, P.N., San, H.T., 1993. Mangroves of Vietnam. IUCN Wetlands Programme. Gland, Switzerland, $173 \mathrm{pp}$.

Humbert, H., Cours-Darne, G., 1965. Notice de la carte de Madagascar. Travaux de la Section Scientifique et Technique de l'Institut Français de Pondichéry 6 , $162 \mathrm{pp}$.

Ioniarilala, R, 2000. Les impacts écologiques de la crevetticulture industrielle sur l'écosystème mangrove, cas de la région de Besalampy. Ecole Supérieure des Sciences Agronomiques de l'Université d'Antananarivo, Madagascar. $68 \mathrm{pp}$

Jimenez, J.A., 1990. The structure and function of dry weather mangroves on the Pacific coast of Central America, with emphasis on Avicennia bicolor forests. Estuaries 13, 182-192.

Kiener, A., 1966. Contribution à l'étude écologique et biologique des eaux saumâtres malgaches. Vie et milieu 16, 1013-1149.

Kiener, A., 1972. Ecologie, biologie et possibilités de mise en valeur des mangroves malgaches. Bulletin de Madagascar 308, 49-80.

Komiyama, A., Santiean, T., Higo, M., Kongsangchai, J., Ogino, K., 1996. Microphotography, soil hardness and survival of mangrove (Rhizophora apiculata) seedlings planted in an abandoned tin-mining area. Forest Ecology and Management 81, 243-248.

Lebigre, J.M., 1984. Problématique de recherches sur les marais maritimes de Madagascar en vue de leur protection et leur aménagement. Revue de Géographie 44, 45-74.

Lebigre, J.M., 1999. Natural spatial dynamics of mangals through their margins: diagnostic elements. Hydrobiologia 413, 103-113.

Macnae, W., 1963. Mangrove swamps in South Africa. Journal of Ecology 51, 1-25. Mumby, P.J., Edwards, A.J., Arias-Gonzalez, J.E., Lindeman, K.C., Blackwell, P.G., Gall, A., Gorczynska, M.I., Harborne, A.R., Pescod, C.L., Renken, H., Wabnitz, C.C.C., Llewellyn, G., 2004. Mangroves enhance the biomass of coral reef fish communities in the Caribbean. Nature 427, 533-536.

Oliva, P., Salomon, J.N., 1984. Le delta de Mangoky et sa région (Madagascar). Cartographie par télédétection spatiale. Travaux et Documents de Géographie Tropicale CEGET 51, 169-197.

Pasqualini, V., Iltis, J., Dessay, N., LointierR, M., Guerlorget, O., Polidori, L., 1999. Mangrove mapping in North-Western Madagascar using SPOT-XS and SIR-C radar data. Hydrobiologia 413, 127-133. 
PNUD, 1998. Rapport mondial sur le développement humain 1998. In: Programme des Nations Unies pour le Développement, Economica, Paris, France, 254 pp.

Rakotomavo, A., 2010. Etat des lieux et dynamique de la mangrove du delta de Mangoky (Sud-Ouest de Madagascar). Thèse de Doctorat. Ecole Supérieure des Sciences Agronomiques, Université d'Antananarivo, 170 pp.

Rakotomavo, A., Fromard, F. 2009. Stratégies d'utilisation des ressources végétales chez les Vezo et les Masikoro du delta de Mangoky. Bois et forêts des Tropiques 300 (2), 45-55.

Ramirez-Garcia, P., Jorge Lopez-Blanco, J., Ocana, D., 1998. Mangrove vegetation assessment in the Santiago River Mouth, Mexico, by means of supervised classification using Landsat TM imagery. Forest Ecology and Management 105, 217-219.

Ranaivoson, J., 1998. Etude du schéma d'aménagement de l'aquaculture de crevettes à Madagascar. Rapport Final. Consortium OSIPD/FTM/PHD/ORSTOM, 38 pp.

Rasolofo, V.M. 1993. Les mangroves de Madagascar in: Diop, E.S. (Ed.), Conservation et utilisation rationnelle des forêts de mangrove de l'Amérique Latine et de l'Afrique, II ITTO/ISME Project PD114/90 (F), pp. 248-265.
Rasolofoharinoro, M., Blasco, F., Bellan, M.F., Aizpuru, M., Gauquelin, T., Denis, J., 1998. A remote sensing based methodology for mangrove studies in Madagascar. International Journal of Remote sensing 19, 1873-1886.

Salomon, J.N., 1987. Le sud-ouest de Madagascar. Université Aix-Marseille, France, $998 \mathrm{pp}$.

SECA, 1986. Les mangroves d'Afrique et de Madagascar, protection et mise en valeur. Rapport du Centre d'Etudes de l'Environnement, Université de Leyde, $94 \mathrm{pp}$.

Southworth, J., 2004. An assessment of Landsat TM band 6 thermal data for analysing land cover in tropical dry forest regions International. Journal of Remote Sensing 25 (4), 689-706.

Spalding, M., Blasco, F., Field, C. (Eds.), 1997. World Mangrove Atlas. The International Society for Mangrove Ecosystems, Okinawa, Japan, 178 pp.

Valiela, I., Bowen, J.L., York, J.K., 2001. Mangrove forests: one of the world's threatened major tropical environments. Bioscience 5, 807-815.

Weiss, H., 1972. Etude phytosociologique des mangroves de la région de Tuléar, Madagascar. Laboratoire de Phytosociologie et cartographie. Université Marseille-St-Charles, France. TETHYS 3, 297-319. 